\title{
THE RELATIONSHIP BETWEEN COMMUNICATIONS EDUCATION AND MEDIA SECTOR IN THE PERIOD OF MEDIA TRAINING
}

\author{
Özden CANKAYA \\ İstanbul Aydın University, Turkey \\ ozdencankaya@aydin.edu.tr \\ Aysun KÖKTENER \\ İstanbul Aydın University, Turkey \\ aysunkoktener@,aydin.edu.tr
}

\begin{abstract}
The aim of this study is to examine and interpret the relationships between communications education and media sector in the period of media colleges. The relationships are discussed under four main titles such as "Participation of Press Sector Professionals in the Communications Education, Opportunities and conditions for students to have training in the media sector in that period, 'Schooled vs. self-educated' debates which were very intensive in that period, Chances and opportunities for those who study communications to find a job in the media sector".
\end{abstract}

Keywords: communication, communication education, media sector

\section{İLETIŞIM EĞITIMI SÜRECINDE ILETIŞIM EĞITTIMI VE MEDYA SEKTÖRÜ ARASINDAKİ İLIŞKI}

\section{ÖZ}

$\mathrm{Bu}$ çalışmanın amacı, iletişim eğitimi sürecisinde iletişim eğitimi ve medya sektörü arasındaki ilişkileri incelemek ve yorumlamaktır. Bu ilișkiler; “ İletişim eğitiminde basın sektöründeki profesyonellerin katılımı, İletişim eğitimine sahip öğrencilerin medya sektöründeki fırsatları ve durumları, Bu süreçte yoğun olan "okullu- alaylı" tartışmaları ve İletişim eğitimi almışların medya sektöründe iş bulmadaki şansları ve firsatları" gibi dört ana başlık altında ele alınmıştır.

Anahtar Kelimeler: iletişim, iletişim eğitimi, medya sektörü

\section{INTRODUCTION}

Communications education started as 'journalism education' in Turkey. Its interaction with media started with the printed press and followed by audio and visual press. The existence of such relationship is natural, because those who studied communications in the early periods also aimed to work in the media sector. This study is limited to look at the media (press) sector relationships of those who were students in that period and organizations providing training in this area, following the start of journalism education and the opening of schools in the area of media. Such relationships can be discussed under four main titles:

1- Participation of Press Sector Professionals in the Communications Education;

2- Opportunities and conditions for students to have training in the media sector in that period;

3- "Schooled vs. self-educated" debates which were very intensive in that period;

4- Chances and opportunities for those who study communications to find a job in the media sector.

\section{START OF JOURNALISM EDUCATION}

Looking at the starting days of journalism education, we see that the first suggestion in this respect came from the media sector. The first initiative for the commencement of journalism education was made by Sedat Simavi in 1947, the Chairman of the Journalists' Society back then. Sedat Simavi sent 
the İstanbul University Rectorate a letter requesting the establishment of an institute for journalism education. The rectorate welcomed the suggestion. The İstanbul University Senate decided for the establishment of a Journalism Institute within the Economy Faculty on November 24, 1949.

The Journalism Institute started education with 479 students in 1950. Professional journalists wished to be students to have a university degree. Police officers also attended the Institute to get a university diploma.

Finding an academician to give lectures turned out to be the largest problem in the early years. In those years, journalists were raised in the profession, with no education on journalism. Only two journalists, Ahmet Emin Yalman and Zekeriya Sertel, had studied journalism. Zekeriya Sertel was living abroad, and Ahmet Emin Yalman had no time to lecture. It was up to Cevat Fehmi Başkut, Chairman of the Journalists' Society, Enis Tahsin Til, Hasan Refik Ertuğ, Burhan Felek and Şükrü Baban to assume the task of lecturing. In early years, general culture classes gained prevalence. Those hard early years of the İstanbul Journalism Institute continued until the establishment of the İstanbul Media College (Topuz, 2003: 93). Following the enactment of the Private Educational Organizations Law in June 1965, the first Private Journalism School was opened in İstanbul in 1966 which was followed by Başkent Private Journalism School opened in Ankara 1967 and İzmir Karataş Private Journalism School (Tokgöz, 2003:16). However, it was decided under a law enacted in 1971 to nationalize private colleges. The three Private Journalism Colleges were affiliated to the Economic and Commercial Sciences Academies in the cities where they were located. (Altun, 1995:111)

\section{COMMUNICATION TRAINING AT THE PRESENT TIME}

Communication Training at the present time is given Faculty Of Communication and Faculty Of Communication Sciences, Faculty Of Fine Arts, Faculty Of Art, Design And Architecture, Faculty Of Fine Arts And Architecture, Faculty Of Arts And Design, Faculty Of Fine Arts And Design, Faculty Of Architecture And Design, Faculty Of Arts And Social Sciences, Academy Of Applied Sciences, Faculty Of Humanities And Social Sciences, Faculty Of Business Management, Faculty Of Economics Adminıstratıve And Social Sciences, Faculty Of Humanities And Letters, Faculty Of Humanities And Social Sciences, Faculty Of Science And Letters. According to the data of The Council of Higher Education in 2015, communication education is given as undergraduate programs in 123 universities and as associate degree programs in 236 Vocatıonal Traınıng Schools (Özkanal and Özgür, 2017: 8).

A great majority of professional journalists who lectured at the Journalism Institutes is not alive today. For this reason, in search of answers for the questions we classified into four main titles, we had discussions with professional journalists graduated from a Media College. They include competent and renowned figures, namely Ahmet Abakay, Chairman of the Contemporary Journalists' Association; Recep Yaşar, Trustee at the Journalists Society of Turkey; Abdürrahim Sönmez, an advertising company manager; and Alp Birol, a lecturer.

1- Participation of Press Sector Professionals in the Communications Education

Practical classes were given by professional journalists, and radio and television employees in the period of the Media Colleges. Mahmut Tali Öngören from TV, journalist Nihat Subaşı, photographer Ozan Sağdıç, author Cevdet Kudret, and Şevket Evliyagil, the owner of Ajans Türk, lectured in Ankara. In İstanbul, well-known figures such as Abdi İpekçi were lecturing. In general, there were no practical profession classes in the first two years. Such classes as Turkish, law, art history, international relationships, social psychology, accounting, statistics, press law were given.

'Ziya Nebioğlu, a journalist from the sector, lectured on page layout and Mehmet Turaç, on public relations. There was practice only in the page layout class, when draft plans of newspaper pages were drawn. Page 1 of a newspaper was being modelled on an A4 paper, but news could not be placed fully. And the lecturer of the public relations class required us to prepare a project for promotion of a company. Typewriting was the class I most benefited by in my career. I learnt touch typing and still use such skills. 
'Guest lecturers were invited to our public relations classes, such as well-known PR agent Betül Mardin.' (Recep Yaşar)

'The journalism teacher Nihat Subaşı took us to various newspapers at Rüzgarlı Sokak, Ankara, giving information on practice. The school had no camera, Güner Sarığlu brought his own one. The camera we touched for the first time was our teacher's .'(Ahmet Abakay)

'Practice opportunities were not sufficient; there was a lack of tools and equipment. There was a 16 $\mathrm{mm}$. camera. Students took turns to zoom looking through the viewfinder. Every person could look only once during a class hour. We wanted to shoot a film with the $16 \mathrm{~mm}$. camera. The school management required mortgage on some property of ours. They were afraid of the camera being damaged. So, we couldn't get it.'(Alp Birol)

2-Opportunities and Conditions for Students to Have Training in the Media Sector In the early periods of communications education, students met their needs of practice by attending training, since the schools had no printing units, radio-television studios, or advertising and news agencies. The following is what professionals we discussed with remember from their college days:

'Compulsory training started at the Marmara Media College for the first time in the 1982-1983 educational term, when I was a student. Students attended training in various areas of the sector according to own preferences, e.g. newspaper, radio, television, public relations and advertising companies. I had training at the TRT İstanbul Television, working on shooting, and as a studio chief and a vision mixer (on regie desk). It was very useful for me. I got introduced to leading journalists such as Uğur Dündar and Savaş Ay. And this was an important advantage provided by the training.' (Alp Birol)

'Our school in Ankara provided us with a training opportunity in our $3^{\text {rd }}$ year. We had training at TRT or leading newspapers, depending on our sections. Training was provided by the school management. I had my training at TRT News Center in 1974. News managers allowed us to accompany the correspondents going out for news. Correspondents who graduated before us treated us very closely and warmly.' (Ahmet Abakay)

Not all who had training at newspapers were of the same opinion:

'I cannot say that I was much welcomed at my place of training. Nobody spoke to me a few days. Professional information sharing was very limited. I had my training at Cumhuriyet Newspaper. Those who shared their professional knowledge with me were limited to 2-3 people.' (Recep Yaşar)

There were also professionals whose training opportunity was provided by their class lecturer.

'I had my training in a film studio thanks to the support by our cinema class lecturer.' (A. Sönmez)

3-"Schooled vs. self-educated" debates which were very intensive in that period

A part of students of that period say they were not affected much by such debates. If there were employees who graduated from the same school previously at the training place, this proved to be an advantage. Professionals of today whom we asked for a comment indicated that the schooled vs. selfeducated debate of that period was mostly among journalists.

'I met no such discrimination at TRT. But it was at the newspapers. "You are born as a journalist, yet cannot become one", I remember those words I heard very often then.(Alp Birol)

'When they learned that we were from a school, people acted with more interest, but were unwilling to share their knowledge right away. Flow of knowledge would start only after trust is established, that is, after the trainee's potential, capacity, respect and interest should be witnessed.'(R.Yaşar)

There were intensive "self-educated vs. schooled" debates in those years. Professionals of that period thought journalism could not be taught at school. Those who were students back then taught professionals saw them as potential competitors and so they didn't choose to transfer their professional knowledge. 
'Self-educated ones first appeared a step ahead of the schooled in terms of professional concepts, news writing, and taking photographs. But we were different owing to the way to see events and the abundant information brought by classes received in almost all areas. (R. Yaşar)

We may say the schooled vs. self-educated debate resulted from a lack of experience in practice of trainees and graduates from the school and from a feeling of competition vis-à-vis young people arriving there with diversified information and a broad perspective. Professionals of that period were using this schooled vs. self-educated concept almost as a shield to protect themselves from the competition of young communicators with theoretic information on law, economy, sociology, socialpsychology, statistics, literature and ethics.

4-Chances and opportunities for those who study communications to find a job in the media sector The problem of finding jobs was experienced also in the early periods of communications education. The professionals we interviewed expressed partly different opinions regarding this matter. There are those who say job opportunities were very limited even back then.

'Very few of the Media College graduates could find a job in the press sector. The majority of graduates had to work in other areas. Being a graduate from those schools was not providing an advantage to be a journalist in those years. (R.Yaşar)

Those who disagree say there were opportunities for recruitment, as there were a less number of graduates of communications education in that period.

'Our school had a quota of 200 students in that period. Graduates had a chance - albeit low - to find to a job. Ways to find to a job were clear for those with desire and curiosity to learn. Intellectual background was given more importance.' (A.Birol)

'Finding a job was difficult for them. 40 people graduated in 1975. However, 20 of them could find a job in the printed or visual press. Others worked in areas other than communications.'(A.Abakay)

Yet, another professional says:

'The master-apprentice relationship was very important in the past. Modest trainees eager to learn were told that they could make a job application. Now it is possible to say those who have not received communications education cling to job more strongly. Understanding of concepts and information in this area takes time, but even those who do not hold a communications degree also stand a chance to find a job.'(A. Sönmez)

\section{CONCLUSION}

According to Arik, communication education can be assessed an area covers theoretical and practical education that multi discipliner branch of social sciences. Communication education is needed to produce intellectual knowledge to educate all personnel that needed to communication sector (2011:81). Therefore communication education has to be arranged to raise intellectuals who have both amateur and professional spirit (Öztürk, 2011:145). Nowadays communication education is given as undergraduate programs in 123 universities and as associate degree programs in 236 vocational training schools. Their graduates complete their studies with more technological information and practical experience vs. early periods. However, media market can not produce employment at the same rate with communication faculties. Because of this, market selects carefully its employment among these graduated students. Therefore, people who graduated from communication faculties do not have a chance to work in media market (Şeker and Şeker, 2011: 99).

We can reach the following conclusions based on an analysis of early periods in comparison to today: While the low number of graduates was an advantage in early years, the high numbers today is a disadvantage in finding a job. Present graduates, hoping to find a job, work as trainees for either zero or very low wages. As they will require more wages when they become equipped and experienced in the area they work, the employer welcomes other new trainees. 
Those stepping into the profession in a master-apprentice relationship in the early periods could find jobs as part of interpersonal relationships and profession traditions. While the one who was skilful and sophisticated had more chance to get himself accepted, the principle of employing at a lower wage and obtaining more profits (profit maximization) works in today's capitalist economy. Considering the mainstream media's policies on the freedom of expression and the staffing tendencies of public service broadcasting, it may be concluded that media college graduates had more chance to find a job in the media sector in the early periods.

\section{REFERENCES}

Arık, B. ve Bayram, F. (2011) "İletişim Eğitimi ve İletişim Akademisyenleri: Veriler Işığında Genel Bir Değerlendirme”, Akdeniz Üniversitesi İletişim Fakültesi Dergisi, S.15: 81-98

Altun, A. (1995) Türkiye'de Gazetecilik ve Gazeteciler, Ankara, Çağdaş Gazeteciler Derneği Yayınları

Özkanal, B. ve Özgür, A.Z. (2017) “Türkiye'de Yükseköğretimde Açık ve Uzaktan Öğrenme Yöntemi İle İletişim Eğitimi Üzerine Değerlendirmeler" Selçuk İletişim Dergisi, 9 (4): 5-24

Öztürk, S. (2011) “İletişim Eğitiminin Hedefi: Yeni Bir Entellektüel Yaratmak” Akdeniz Üniversitesi İletişim Fakültesi Dergisi, S.15:145-156

Şeker, M. ve Şeker, T. (2011) "İletişim Eğitiminde Temel Sorunlar ve Açmazlar"

Akdeniz Üniversitesi İletişim Fakültesi Dergisi, S.15:99-118

Tokgöz, O. (2003) Türkiye'de İletişim Eğitimi: Elli Yıllık Bir Geçmişin Değerlendirilmesi, Kültür ve İletişim, 6 (2) 7-32

Topuz, H. (2003) II. Mahmut'tan Holdinglere Türk Basın Tarihi, İstanbul: Remzi Kitabevi

The Interview with Abdürrahim Sönmez, 20 September 2012.

The Interview with Ahmet Abakay, 30 September 2012.

The Interview with Alp Birol, 25 September 2012.

The Interview with Recep Yaşar, 03 October 2012. 